\title{
Cost Benefit Analysis of Growing Cucumbers in Greenhouse at Different Cooling of Nutrient Solution Temperatures in Closed Hydroponic System in Oman
}

\author{
Muthir Saleh Said Al Rawahy ${ }^{1} \&$ Msafiri Daudi Mbaga ${ }^{2}$ \\ ${ }^{1}$ Head of Vegetable Crops Research Section Directorate General of Agriculture and Livestock Research, Oman \\ ${ }^{2}$ Associate Professor, Department of Natural Resource, Sultan Qaboos University, College of Agricultural and \\ Marine Sciences, PO BOX 34, Postal Code 123, Al-Khodh, Muscat, Oman \\ Correspondence: Dr. Msafiri Daudi Mbaga, Department of Natural Resource, Sultan Qaboos University, College \\ of Agricultural and Marine Sciences, PO BOX 34, Postal Code 123, Al-Khodh, Muscat, Oman. Tel: \\ 968-2414-3669. E-mail: msafiri@squ.edu.om
}

Received: November 22, 2018 Accepted: December 12, 2018 Online Published: January 4, 2019

doi:10.5539/sar.v8n1p74

URL: https://doi.org/10.5539/sar.v8n1p74

\begin{abstract}
Oman is a country that is mostly dry and hot, with daily maximum temperatures easily reaching $40^{\circ} \mathrm{C}$ or more during summer. The Oman weather therefore renders conventional open field agriculture almost impossible. The sustainable future of agriculture in Oman and other similar desert countries will therefore depend very much on the adoption of land and water saving technologies such as greenhouses and soilless culture or hydroponics. Soilless culture (Hydroponics) is the technique of growing plants without soil with their roots immersed in nutrient solution. Among factors affecting hydroponic production systems, is the nutrient solution temperature which is considered to be one of the most important determining factors of crop yield and quality. The aim of this research is therefore to investigate the economic effect of cooling nutrient solutions temperature technique on cucumber output. Four nutrient solutions temperatures are investigated and a Cost Benefit Analysis is undertaken. Results indicate that all the four cooling nutrient temperature yields positive returns (benefits) above variable and total costs for the two years of this experiment. Cooling nutrient temperature $\left(22^{\circ} \mathrm{C}\right)$ yields higher returns than the other treatments followed by treatment $\left(25^{\circ} \mathrm{C}\right),\left(28^{\circ} \mathrm{C}\right)$ and then the CONTROL treatment. Returns for the second year are higher than the first year. Therefore treatment $\left(22^{\circ} \mathrm{C}\right)$ was observed to be the best overall producing the highest return above variable and total costs. It is therefore considered the best alternative for cucumber growers.
\end{abstract}

Keywords: cost, benefit, greenhouse, cucumber, cooling solution, soilless culture

\section{Introduction and Background}

Cucumber cultivation in greenhouses currently plays a very important role in Oman and other desert countries. In fact, this will continue to be so, as vegetable growing in a controlled environment continues to expand in these countries. This is because one of the most serious constrains facing agriculture in Oman and other desert countries include shortage of land and suitable water for agriculture. Oman is a country that is mostly dry and hot, with daily maximum temperatures temperature easily reaching $40^{\circ} \mathrm{C}$ or more during summer. Winters are cooler with occasional rainfalls. However, in spring and summer seasons a hot, and dusty wind (the Shamal), blows making it very hot and unbearable. To overcome this, farmers have historically resorted to digging wells and pumping water in order to carry out farming. With time, this has however proved to be unsustainable and destructive because it has resulted into sea water intrusion and hence soil salinity especially in the Batinah coast. The Oman weather therefore renders conventional open field agriculture almost impossible. As highlighted in Mbaga (2013; 2014) and (Mbaga et al., 2018) as well as by a number of other authors on this subject matter, the sustainable future of agriculture in Oman and other similar desert countries will depend very much on the adoption of land and water saving technologies such as greenhouses and soilless culture or hydroponics. Soilless culture (Hydroponics) is the technique of growing plants without soil with their roots immersed in nutrient solution (Maharana and Koul, 2011). Among factors affecting hydroponic production systems, is the nutrient solution temperature which is considered to be one of the most important determining factors of crop yield and 
quality. The temperature of the nutrient solution influences the uptake of water and nutrients differentially by the crop (Maharana and Koul, 2011). There are a wide range of research works done over the years on the combinations of these technologies with very promising results e.g., Al-Helal, (2007); Al-Helal and Al-Hamdan, (2009); Al-Ismaili and Jayasuriya, (2016) and Al-Ismaili et al., (2018). Farmers using hydroponic system in greenhouses to grow vegetables in Oman face the challenge of high temperature of nutrient solution in feeding tanks especially in summer season when temperatures reach above 40 degrees centigrade. The aim of this research work is therefore to investigate the economic effect of cooling nutrient solutions temperature technique on cucumber output. The four nutrient solutions temperatures are: (i) Treatment $1\left(22^{\circ} \mathrm{C}\right)$, (ii) Treatment $2(25$ $\left.{ }^{\circ} \mathrm{C}\right)$, (iii) Treatment $3\left(28^{\circ} \mathrm{C}\right)$ and (iv) Treatment $4\left(33^{\circ} \mathrm{C}\right)$ as CONTROL.

\section{Materials and Methods.}

The experiments were conducted in a cooled greenhouse of dimension $30 \mathrm{~m}$ long $\mathrm{x} 9 \mathrm{~m}$ wide at the Directorate General of Agriculture and Livestock Research in Rumais, Barka around $40 \mathrm{~km}$ north of capital Muscat during three periods of growing cucumber under hydroponics viz., summer temperature period (June-August), fall temperature period (September-November) and spring temperature period (February-May) for two years during 2016/ 2017and 2017/2018. We investigate the economic effect on cucumber output at three Root-Zone Temperatures (Hereafter RZT) of cooling nutrient solution viz. RZT1 $\left(22^{\circ} \mathrm{C}\right)$, RZT2 $\left(25^{\circ} \mathrm{C}\right)$ and RZT3 $\left(28^{\circ} \mathrm{C}\right)$. Besides the three RZT we have the control-uncooled nutrient solution RZT4 $\left(33^{\circ} \mathrm{C}\right)$ that had root-zone ambient temperature of over $33^{\circ} \mathrm{C}$. The experiment was arranged in Randomized Complete Design (RCD) with four replications. Each temperature treatment was equipped with cooling system connected with electricity meter in order to record the power consumption during the course of the experiment. Appendices I and II present raw data in terms of cost of materials (cooling system and stock solution), labour, power consumption per treatment and cucumber output (yield $\mathrm{kg} / \mathrm{GH}$ ) for each of the three cropping period (June-August, September-November and February-May) in a year. The experiment was carried out over a period of two years 2016/2017 (Appendix I) and 2017/2018 (Appendix II). In both years 1 and 2 cucumber price was high during cropping period (June-August) at 0.400 Baiza, as compared to 0.200 Baiza for September-November and February-May cropping periods. Greenhouse Investment Costs (Fixed Costs) for Cucumber Production for this experiment is as indicated in Table1 below. As in other similar studies such as: Smith et.al. 1990; Sengar, and Kothari, (2008); and Chito, (2007) we assume here that contract labor is used to construct the greenhouse. Straight line depreciation approach is used on all items. The depreciation period for each item is as shown in Table 1. An interest charge of $9 \%$ is made to the average investment (half the initial cost) of each item as in previous studies above. Taxes and insurance are assumed to be $1.25 \%$ of the original investment.

Table 1. Greenhouse Investment Costs (Fixed Costs) for Cucumber Production in Oman

\begin{tabular}{llllllcc}
\hline Construction & Original cost & Life Yrs & Depr. & Interest ${ }^{* *}$ & $\begin{array}{c}\text { Tax }+ \\
\text { Insur }\end{array}$ & $\begin{array}{c}\text { Annual maint. } \\
\text { Cost }\end{array}$ & Annualized \\
\hline $\begin{array}{l}\text { 1. Construction cost of cooling } \\
\text { system for one temp. treatment }\end{array}$ & 239.000 & 5 & 47.800 & 10.755 & 2.988 & 10.000 & 71.543 \\
2. Costs of channels & 160.000 & 5 & 32.000 & 7.200 & 2.000 & 0.000 & 41.200 \\
3. Cost of labor for installation & 200.000 & 5 & 40.000 & 9.000 & 2.500 & 0.000 & 51.500 \\
4. Cables DP outside to DP inside GH & 45.000 & 5 & 9.000 & 2.025 & 0.563 & 0.000 & 11.588 \\
5. Cables DP inside GH to coolers & 7.500 & 5 & 1.500 & 0.338 & 0.094 & 0.000 & 1.931 \\
Total Constr. Cost & 651.500 & & 130.300 & 29.318 & 8.144 & 10.000 & 177.761 \\
\hline
\end{tabular}

Note: "Taxes and Insurance rate $\%=1.3$. Currency is in Rial Oman $(\mathrm{RO}) \approx 2.58$ US\$

${ }^{* * *}$ Interest rates $\%=9$

As presented on Table 1 above the construction costs of a cooled greenhouse of dimension $30 \mathrm{~m}$ long $\mathrm{x} 9 \mathrm{~m}$ wide used for this experiment amounted to RO 651.500. The depreciation costs are RO130.300, Interest charges are RO29.318, Tax and Insurance costs are RO8.144 and Annual maintenance costs are RO10.00. As a result, the annualized costs (amount to be charged each year on the enterprise in relation to initial investment costs) are RO. 177.761 .

\section{Results and Discussion}

Based on the data presented in Appendix I and Appendix II, the variable costs associated with each of the four (4) treatments RZT $\left(22^{\circ} \mathrm{C}\right)$, RZT $\left(25^{\circ} \mathrm{C}\right)$, RZT $\left(28^{\circ} \mathrm{C}\right)$ and the control RZT $\left(33^{\circ} \mathrm{C}\right)$ were calculated for the two years for which this experiment was undertaken. The results are as presented in Table 2 (Year one) and Table 3 (Year two). 
The Total Variable Costs for year one are RO. 862.79, RO. 859.09, RO. 848.39 and RO. 839.19 for RZT $\left(22^{\circ} \mathrm{C}\right)$, RZT $\left(25^{\circ} \mathrm{C}\right)$, RZT $\left(28^{\circ} \mathrm{C}\right)$, RZT $\left(33^{\circ} \mathrm{C}\right)$ respectively. Therefore the Total Variable Costs for RZT $\left(22^{\circ} \mathrm{C}\right)$ were the highest and the Total Variable Costs for Treatment $4\left(33^{\circ} \mathrm{C}\right)$ were the lowest. RZT $\left(22^{\circ} \mathrm{C}\right)$ consumed more power than the other three treatments.

Table 2. Total Variable Costs per Treatment Year One

\begin{tabular}{|c|c|c|c|c|}
\hline \multicolumn{5}{|l|}{ VARIABLE COSTS } \\
\hline $\mathrm{RZT}\left(22^{\circ} \mathrm{C}\right)$ & June - Aug & Sept - Nov & Feb-May & Annual VAR. COST \\
\hline Labor & 180.00 & 180.00 & 180.00 & 540.00 \\
\hline Seeds & 50.00 & 50.00 & 50.00 & 150.00 \\
\hline Chemicals & 33.33 & 33.33 & 33.33 & 99.99 \\
\hline Cost of stock solution & 16.40 & 16.40 & 16.40 & 49.20 \\
\hline Power & 10.60 & 6.00 & 7.00 & 23.60 \\
\hline \multicolumn{4}{|c|}{ Total Variable Costs RZT $\left(22^{\circ} \mathrm{C}\right)$} & 862.79 \\
\hline $\operatorname{RZT}\left(25^{\circ} \mathrm{C}\right)$ & June - Aug & Sept - Nov & Feb-May & Annual VAR. COST \\
\hline Labor & 180.00 & 180.00 & 180.00 & 540.00 \\
\hline Seeds & 50.00 & 50.00 & 50.00 & 150.00 \\
\hline Chemicals & 33.33 & 33.33 & 33.33 & 99.99 \\
\hline Cost of stock solution & 16.40 & 16.40 & 16.40 & 49.20 \\
\hline Power & 9.50 & 5.40 & 5.00 & 19.90 \\
\hline \multicolumn{4}{|c|}{ Total Variable Costs RZT $\left(25^{\circ} \mathrm{C}\right)$} & 859.09 \\
\hline $\mathrm{RZT}\left(28^{\circ} \mathrm{C}\right)$ & June - Aug & Sept - Nov & Feb-May & Annual VAR. COST \\
\hline Labor & 180.00 & 180.00 & 180.00 & 540.00 \\
\hline Seeds & 50.00 & 50.00 & 50.00 & 150.00 \\
\hline Chemicals & 33.33 & 33.33 & 33.33 & 99.99 \\
\hline Cost of stock solution & 16.40 & 16.40 & 16.40 & 49.20 \\
\hline Power & 5.80 & 1.80 & 1.60 & 9.20 \\
\hline \multicolumn{4}{|c|}{ Total Variable Costs RZT $\left(28^{\circ} \mathrm{C}\right)$} & 848.39 \\
\hline \multicolumn{5}{|c|}{ CONTROL } \\
\hline $\operatorname{RZT}\left(33^{\circ} \mathrm{C}\right)$ & June - Aug & Sept - Nov & Feb-May & Annual VAR. COST \\
\hline Labor & 180.00 & 180.00 & 180.00 & 540.00 \\
\hline Seeds & 50.00 & 50.00 & 50.00 & 150.00 \\
\hline Chemicals & 33.33 & 33.33 & 33.33 & 99.99 \\
\hline Cost of stock solution & 16.40 & 16.40 & 16.40 & 49.20 \\
\hline \multicolumn{4}{|c|}{ Total Variable Costs CONTROL RZT $\left(33^{\circ} \mathrm{C}\right)$} & 839.19 \\
\hline
\end{tabular}


Table 3. Total Variable Costs per Treatment Year Two

\begin{tabular}{|c|c|c|c|c|}
\hline \multicolumn{5}{|l|}{ VARIABLE COSTS } \\
\hline $\operatorname{RZT}\left(22^{\circ} \mathrm{C}\right)$ & June - Aug & Sept - Nov & Feb-May & Annual VAR. COST \\
\hline Labor & 180.00 & 180.00 & 180.00 & 540.00 \\
\hline Seeds & 50.00 & 50.00 & 50.00 & 150.00 \\
\hline Chemicals & 33.33 & 33.33 & 33.33 & 99.99 \\
\hline Cost of stock soln. & 16.40 & 16.40 & 16.40 & 49.20 \\
\hline Power & 10.60 & 6.10 & 8.80 & 25.50 \\
\hline \multicolumn{4}{|c|}{ Total Variable Costs RZT $\left(22^{\circ} \mathrm{C}\right)$} & 864.70 \\
\hline $\operatorname{RZT}\left(25^{\circ} \mathrm{C}\right)$ & June - Aug & Sept - Nov & Feb-May & Annual VAR. COST \\
\hline Labor & 180.00 & 180.00 & 180.00 & 540.00 \\
\hline Seeds & 50.00 & 50.00 & 50.00 & 150.00 \\
\hline Chemicals & 33.33 & 33.33 & 33.33 & 99.99 \\
\hline Cost of stock solution & 16.40 & 16.40 & 16.40 & 49.20 \\
\hline Power & 9.60 & 5.60 & 5.20 & 20.40 \\
\hline \multicolumn{4}{|c|}{ Total Variable Costs RZT $\left(25^{\circ} \mathrm{C}\right)$} & 859.60 \\
\hline $\operatorname{RZT}\left(28^{\circ} \mathrm{C}\right)$ & June - Aug & Sept - Nov & Feb-May & Annual VAR. COST \\
\hline Labor & 180.00 & 180.00 & 180.00 & 540.00 \\
\hline Seeds & 50.00 & 50.00 & 50.00 & 150.00 \\
\hline Chemicals & 33.33 & 33.33 & 33.33 & 99.99 \\
\hline Cost of stock solution & 16.40 & 16.40 & 16.40 & 49.20 \\
\hline Power & 5.80 & 1.80 & 2.44 & 10.04 \\
\hline \multicolumn{4}{|c|}{ Total Variable Costs RZT $\left(28^{\circ} \mathrm{C}\right)$} & 849.23 \\
\hline \multicolumn{5}{|c|}{ CONTROL Treatment 4} \\
\hline $\operatorname{RZT}\left(33^{\circ} \mathrm{C}\right)$ & June - Aug & Sept - Nov & Feb-May & Annual VAR. COST \\
\hline Labor & 180.00 & 180.00 & 180.00 & 540.00 \\
\hline Seeds & 50.00 & 50.00 & 50.00 & 150.00 \\
\hline Chemicals & 33.33 & 33.33 & 33.33 & 99.99 \\
\hline Cost of stock solution & 16.40 & 16.40 & 16.40 & 49.20 \\
\hline \multicolumn{4}{|c|}{ Total Variable Costs CONTROL RZT $\left(33^{\circ} \mathrm{C}\right)$} & 839.19 \\
\hline
\end{tabular}

As indicated in Table 3 above results for this experiment in the second year produced a comparable pattern in that the Total Variable Costs for RZT $\left(22^{\circ} \mathrm{C}\right)$ were the highest and the Total Variable Costs for RZT $\left(33^{\circ} \mathrm{C}\right)$ were the lowest. Similarly, RZT $\left(22^{\circ} \mathrm{C}\right)$ consumed more power than the other three treatments.

Table 4. Seasonal and Annual Revenue per Treatment Year One

\begin{tabular}{lllll}
\hline Treatments & June - Aug & Sept - Nov & Feb-May & Annual revenue \\
\hline RZT $\left(22^{\circ} \mathrm{C}\right)$ & $2,000.00$ & $1,280.00$ & $1,540.00$ & $4,820.00$ \\
RZT $\left(25^{\circ} \mathrm{C}\right)$ & $1,760.00$ & $1,400.00$ & $1,600.00$ & $4,760.00$ \\
RZT $\left(28^{\circ} \mathrm{C}\right)$ & $1,880.00$ & $1,200.00$ & $1,160.00$ & $4,240.00$ \\
RZT $\left(33^{\circ} \mathrm{C}\right)$ CONTROL & $1,120.00$ & $1,000.00$ & $1,120.00$ & $3,240.00$ \\
\hline
\end{tabular}

Table 5. Seasonal and Annual Revenue per Treatment Year Two

\begin{tabular}{lllll}
\hline Treatments & June - Aug & Sept - Nov & Feb-May & Annual revenue \\
\hline RZT $\left(22^{\circ} \mathrm{C}\right)$ & $2,440.00$ & $1,700.00$ & $1,700.00$ & $5,840.00$ \\
RZT $\left(25^{\circ} \mathrm{C}\right)$ & $2,400.00$ & $1,740.00$ & $1,520.00$ & $5,660.00$ \\
RZT $\left(28^{\circ} \mathrm{C}\right)$ & $1,520.00$ & $1,400.00$ & $1,420.00$ & $4,340.00$ \\
RZT $\left(33^{\circ} \mathrm{C}\right)$ CONTROL & $1,400.00$ & $1,360.00$ & $1,300.00$ & $4,060.00$ \\
\hline
\end{tabular}

With regard to revenue, seasonal and annual revenue per treatment for year one and year two are as presented in Table 4 and Table 5 above respectively. Apparently RZT $\left(22^{\circ} \mathrm{C}\right)$ registered highest annual revenue at RO. $4,820.000$ during the first year whereas RZT $\left(33^{\circ} \mathrm{C}\right)$ produced the lowest annual revenue at RO 3,240.000.

Similarly during the second year, RZT $\left(22^{\circ} \mathrm{C}\right)$ registered highest annual revenue at RO. 5,840.000, whereas RZT $\left(33^{\circ} \mathrm{C}\right)$ produced the lowest annual revenue at RO 4060.000. Second year annual revenues were higher across all 
four (4) Treatments.

The results of the analysis of the costs and benefits of the four (4) treatments across the three seasons and over the two years of this experiment are as presented in Table 6 and 7 below.

Table 6. Return Above Total and Variable Costs in Oman Rial per Treatment Year One

\begin{tabular}{lllll}
\hline Item & RZT $\left(22^{\circ} \mathrm{C}\right)$ & RZT $\left(25^{\circ} \mathrm{C}\right)$ & RZT $\left(28^{\circ} \mathrm{C}\right)$ & RZT 33 ${ }^{\circ} \mathrm{C}$ \\
\hline Revenue & $4,820.00$ & $4,760.00$ & $4,240.00$ & $3,240.00$ \\
Variable costs & 849.71 & 846.01 & 835.31 & 789.99 \\
Fixed costs & 177.76 & 177.76 & 177.76 & 0.00 \\
Return above variable costs & $3,970.29$ & $3,913.99$ & $3,404.69$ & $2,450.01$ \\
Return above total costs & $3,792.53$ & $3,736.23$ & $3,226.93$ & $2,450.01$ \\
\hline
\end{tabular}

Table 7. Return Above Total and Variable Costs in Oman Rial per Treatment Year Two

\begin{tabular}{lllll}
\hline Item & RZT $\left(22^{\circ} \mathrm{C}\right)$ & RZT $\left(25^{\circ} \mathrm{C}\right)$ & RZT $\left(28^{\circ} \mathrm{C}\right)$ & RZT 33 ${ }^{\circ} \mathrm{C}$ \\
\hline Revenue & $5,840.00$ & $5,660.00$ & $4,340.00$ & $4,060.00$ \\
Variable costs & 851.61 & 846.51 & 836.15 & 789.99 \\
Fixed costs & 177.76 & 177.76 & 177.76 & 0.00 \\
Return above variable costs & $4,988.39$ & $4,813.49$ & $3,503.85$ & $3,270.01$ \\
Return above total costs & $4,810.63$ & $4,635.73$ & $3,326.09$ & $3,270.01$ \\
\hline
\end{tabular}

As indicated in the last two rows of Table 6 and 7, all the returns above variable costs and returns above total costs for the two years of this experiment are positive and significantly high. Treatment RZT $\left(22^{\circ} \mathrm{C}\right)$ yields highest returns than the other three treatments. This is followed by treatment 2, 3 and then the CONTROL treatment. Returns for the second year are higher than the first year.

Table 8. Return Above Total Costs in Oman Rial per Treatment for Year One and Two

\begin{tabular}{lcc}
\hline Treatments & Year 1 & Year 2 \\
\hline RZT $\left(22^{\circ} \mathrm{C}\right)$ & $3,792.53$ & $4,810.63$ \\
RZT $\left(25^{\circ} \mathrm{C}\right)$ & $3,736.23$ & $4,635.73$ \\
RZT $\left(28^{\circ} \mathrm{C}\right)$ & $3,226.93$ & $3,326.09$ \\
RZT $\left(33^{\circ} \mathrm{C}\right) \mathrm{CONTROL}$ & $2,450.01$ & $3,270.01$ \\
\hline
\end{tabular}

Table 8 above presents a summary of returns above total costs in Oman rials per treatment for the two years. As can be observed in Table 8 above all treatments across all the two years of this experiment yielded positive returns above total costs. Furthermore, RZT $\left(22^{\circ} \mathrm{C}\right)$ was observed to be the best of all producing the highest return above total costs of RO. 3,792.53 during the first year and RO. 4, 810.63 during the second year respectively. This means that cooling nutrient solution to a Root-Zone Temperature of $22^{\circ} \mathrm{C}$ (RZT $22^{\circ} \mathrm{C}$ ) leads to a better economic effect on cucumber output and hence higher return for cucumber farmers.

\section{Conclusion}

Cucumber cultivation in greenhouses currently plays a very important role in Oman and will continue to do so, as vegetable growing in a controlled environment continue to expand in this country. Because of the shortage of land and water, the success of agriculture in Oman depends very much on the adoption of land and water saving technologies such as greenhouses and soilless culture or hydroponics. Among factors affecting hydroponic production systems, is the nutrient solution temperature which is considered to be one of the most important determining factors of crop yield and quality. In this research we conduct the Cost Benefit Analysis of growing Cucumbers in greenhouses at different cooling temperature of nutrient solution in a closed hydroponic system. The four nutrient solutions temperatures investigated are: (i) RZT $\left(22^{\circ} \mathrm{C}\right)$, (ii) $\mathrm{RZT}\left(25^{\circ} \mathrm{C}\right)$, (iii) RZT $\left(28^{\circ} \mathrm{C}\right)$ and (iv) RZT $\left(33^{\circ} \mathrm{C}\right)$ as CONTROL.

Results showed that all four cooling nutrient temperature yielded positive returns (benefits) above variable and total costs for the two years of this experiment. RZT $\left(22^{\circ} \mathrm{C}\right)$ yields highest returns than the other. This is followed by treatment 2, 3 and then the CONTROL treatment. Returns for the second year are higher than the first year. Therefore, RZT $\left(22^{\circ} \mathrm{C}\right)$ was observed to be the best of all producing the highest return above variable and total costs of RO. 3,970.29 and 3,792.53 during the first year and RO. 4,988.39 and RO. 4, 810.63 during the second year respectively. 
At this juncture, pending further experiments at the farm level (Farmer's field) at different regions of the country, results obtained here suggests that cooling solutions at 22 degree centigrade $\left(22^{\circ} \mathrm{C}\right)$ should be adopted by farmers in Oman as it leads to increased yield and hence more benefits to farmers.

\section{Acknowledgement}

The research is financed by Agriculture \& Fisheries Development Fund (AFDF) of the Ministry of Agriculture \& Fisheries, Sultanate of Oman and part of PhD thesis for submission to the Sultan Qaboos University, Sultanate of Oman.

\section{References}

Al-Helal, I. M. (2007). Effects of ventilation rate on the environment of a fan-pad evaporatively cooled, shaded greenhouse in extreme arid climates. Applied Engineering in Agriculture, 23(2), 221-230. https://doi.org/10.13031/2013.22605

Al-Helal, I. M., \& Al-hamdan, A. M. (2009). Effect of arid environment on radiative properties of greenhouse polyethylene cover. Solar Energy, 83(6), 790-798. https://doi.org/10.1016/j.solener.2008.11.008

Al-Ismaili, A. M., \& Jayasuriya, H. (2016). Seawater greenhouse in Oman: A sustainable technique for freshwater conservation and production. Renewable and Sustainable Energy Reviews, 54, 653-664. https://doi.org/10.1016/j.rser.2015.10.016

Al-Ismaili A. M., Jayasuriya, H., Al-Mulla, Y., \& Kotagama, H. (2018). Empirical model forthe condenser of the seawater greenhouse. Chemical Engineering Communications, 205. https://doi.org/10.1080/00986445.2018.1443081.

Chito, F. S. (2007). "Greenhouse Economics.” Philippine Agricultural Mechanization Bulletin. Retrieved from http://ecoursesonline.iasri.res.in/mod/page/view.php?id=1665

Maharana, L., \& Koul, D. N. (2011). The emergence of Hydroponics. Yojana (June), 55, 39-40. Retrieved from https://issuu.com/ijret/docs/a_review_on_plant_without_soil_-_hy/6

Mbaga, M. D. (2013). Alternative Mechanism for Achieving Food Security in Oman. Agriculture and Food Security, 2(3). https://doi.org/10.1186/2048-7010-2-3

Mbaga, M. D. (2015). The Prospects of Desert Agriculture to Improve Food Security in Oman. Consilience: The Journal of Sustainable Development, 13(1), 114-129. https://doi.org/10.7916/D8HM58X6

Mbaga, M., Al Abri, L., Bose, S., \& Boughanmi, H. (2018). Omani Consumer's Ethnocentrism and Demand for Locally Produced Products. American Journal of Industrial and Business Management, 8, 1440-1459. https://doi.org/10.4236/ajibm.2018.86097.

Sengar, S. H., \& Kothari, S. (2008). Economic evaluation of greenhouse for cultivation of rose nursery. African Journal of Agricultural Research, 3(6), 435-439. Retrieved from http://www.academicjournals.org/AJAR

Smith J. L., Hewitt, T. D., Hochmuth, R. C., \& Hochmuth, G. J. (1990). A Profitability and Cash Flow Analysis of Typical Greenhouse Production in North Florida Using Tomato as an Example. Florida Greenhouse Vegetable Production Handbook, 3. Retrieved from https://docplayer.net/storage/25/5290105/1542794897/0VsrAs0o1V5hjtNjewj_Jw/5290105.pdf

\section{Appendix I}

First year 2016/2017 cost

Cost of cooling system for one temperature treatments

\begin{tabular}{llcccc}
\hline $\mathrm{s}$ & Item & quantity & Unit & Unit price O.R & Total price O.R \\
\hline 1 & Cooling coil pipe 1/2 " & 15 & Meter & 15 & 15 \\
2 & Cooling coil pipe 1/4" & 15 & Meter & 8 & 8 \\
3 & Insulation slaves & 12 & No & 0.250 & 3 \\
4 & Digital temperature control & 1 & No & 20 & 20 \\
5 & Antistatic paint & 1 & No & 5 & 5 \\
6 & Conductors 30A single phase & 1 & No & 8 & 8 \\
7 & Isolator switch & 1 & No & 5 & 5 \\
8 & Compressor unit 18000 BTU (1.5) & 1 & No & 160 & 160 \\
9 & Control panel box & 1 & No & 15 & 15 \\
& Grand total O.R & & & & 239 \\
\hline
\end{tabular}


Depreciation every year is $20 \%$ of cooling system unit

Maintenance every year cost 10 O.R

Cost of stock solution for each treatment per Season

\begin{tabular}{lcccc}
\hline \multicolumn{1}{c}{ Fertilizer } & Price in O.R/ 25 Kg & $\begin{array}{c}\text { Quantity used } \\
\text { at each time }\end{array}$ & $\begin{array}{c}\text { Price of quantity } \\
\text { used at each time }\end{array}$ & $\begin{array}{c}\text { Price in each season } \\
\text { O.R }\end{array}$ \\
\hline NPK 12:120:36 & 19 & $3 \mathrm{~kg}$ & $2.28 \times 2$ & 4.56 \\
$\mathrm{Ca}(\mathrm{NO} 3)$ & 8 & $3 \mathrm{kgx} 2$ & $1.92 \times 2$ & 3.84 \\
MgSo4 & 11 & $1.5 \mathrm{kgx} 2$ & $1.32 \times 2$ & 2.64 \\
Iron Chilate & 5 & $100 \mathrm{gx} 2$ & $0.5 \times 2$ & 1.00 \\
Nitric acid & $44 / 20$ liter & 2 liters & 4.4 & 4.4 \\
Total & & & & 16.4 \\
\hline
\end{tabular}

Hint: each treatments prepared same amount of fertilizers used

- Cost of channels $=160$ O.R One time

- Cost of labor for insulation $=2 \times 10 \times 1$ day $=20 \times 10$ days $=200$ O.R

- Cost of labor for culture practice $=2$ rials per labor $/$ day $(3$ months $/$ season $)=360$

- Cost of Seeds (1000 seeds) $=50$ O.R/season

- Cost cables:

$>1$ - from Dp outside to Dp inside $\mathrm{Gh}=10 \mathrm{~m}$ each meter $4.5 \mathrm{O} . \mathrm{R}=4.5 \times 10 \mathrm{~m}=45$ O.R

$>$ 2- From Dp inside Gh to coolers $15 \mathrm{~m}$ 90m cost 45 O.R---15X45/90= 7.5 O.R

- Cost of chemicals: 100 O.R

Power consumption for each temperature per season:

Summer Season (June-August) first year 2016/2017

\begin{tabular}{lccccc}
\hline Treatments & At planting time & End of season & Consumption kw/season & Price per/kw O.R & Total price O.R \\
\hline $\mathrm{T} 1\left(22^{\circ} \mathrm{C}\right)$ & 00884 & 01939 & 1055 & 0.01 & 10.6 \\
$\mathrm{~T} 2\left(25^{\circ} \mathrm{C}\right)$ & 00696 & 01649 & 953 & 0.01 & 9.5 \\
$\mathrm{~T} 3\left(28^{\circ} \mathrm{C}\right)$ & 00217 & 00798 & 581 & 0.01 & 5.8 \\
\hline
\end{tabular}

Fall Season (Sept-Nov) first year 2016/2017

\begin{tabular}{lccccc}
\hline Treatments & At planting time & End of season & Consumption kw/season & Price per/kw O.R & Total price O.R \\
\hline $\mathrm{T} 1\left(22^{\circ} \mathrm{C}\right)$ & 01988 & 02583 & 595 & 0.01 & 6.0 \\
$\mathrm{~T} 2\left(25^{\circ} \mathrm{C}\right)$ & 01703 & 02245 & 542 & 0.01 & 5.4 \\
$\mathrm{~T} 3\left(28^{\circ} \mathrm{C}\right)$ & 00823 & 01005 & 182 & 0.01 & 1.8 \\
\hline
\end{tabular}

Spring Season (Feb-May) first year 2016/2017

\begin{tabular}{lccccc}
\hline Treatments & At planting time & End of season & Consumption kw/season & Price per/kw O.R & Total price O.R \\
\hline $\mathrm{T} 1\left(22^{\circ} \mathrm{C}\right)$ & 00001 & 00696 & 695 & 0.01 & 7 \\
$\mathrm{~T} 2\left(25^{\circ} \mathrm{C}\right)$ & 00155 & 00655 & 500 & 0.01 & 5 \\
$\mathrm{~T} 3\left(28^{\circ} \mathrm{C}\right)$ & 00060 & 00217 & 157 & 0.01 & 1.6 \\
\hline
\end{tabular}

Production of cucumber and price/season for first year 2016/2017

\begin{tabular}{cccccccccc}
\hline RZTs & \multicolumn{3}{c}{ June-August } & \multicolumn{3}{c}{ September-November } & \multicolumn{2}{c}{ February-May } \\
\hline & $\begin{array}{c}\text { Yield } \\
\mathrm{kg} / \mathrm{gh}\end{array}$ & $\begin{array}{l}\text { Price } \\
\text { /kg O.R }\end{array}$ & $\begin{array}{l}\text { Total } \\
\text { income O.R }\end{array}$ & Yield kg/gh & $\begin{array}{l}\text { Price } \\
\text { /kg O.R }\end{array}$ & $\begin{array}{l}\text { Total } \\
\text { income O.R }\end{array}$ & Yield kg/gh & $\begin{array}{l}\text { Price } \\
\text { /kg O.R }\end{array}$ & $\begin{array}{l}\text { Total } \\
\text { income O.R }\end{array}$ \\
\hline $\mathrm{T} 1\left(22^{\circ} \mathrm{C}\right)$ & 5000 & 0.4 & 2000 & 6400 & 0.2 & 1280 & 7700 & 0.2 & 1540 \\
$\mathrm{~T} 2\left(25^{\circ} \mathrm{C}\right)$ & 4400 & 0.4 & 1760 & 7000 & 0.2 & 1400 & 8000 & 0.2 & 1600 \\
$\mathrm{~T} 3\left(28^{\circ} \mathrm{C}\right)$ & 4700 & 0.4 & 1880 & 6000 & 0.2 & 1200 & 5800 & 0.2 & 1160 \\
$\mathrm{~T} 4\left(33^{\circ} \mathrm{C}\right)$ & 2800 & 0.4 & 1120 & 5000 & 0.2 & 1000 & 5600 & 0.2 & 1120 \\
\hline
\end{tabular}


Second year 2017/2018 Cost

Cost of stock solution for each treatment per Season

\begin{tabular}{lllll}
\hline Fertilizer & Price in O.R/25 Kg & $\begin{array}{l}\text { Quantity used } \\
\text { at each time }\end{array}$ & $\begin{array}{l}\text { Price of quantity } \\
\text { used at each time }\end{array}$ & $\begin{array}{l}\text { Price in each season } \\
\text { O.R }\end{array}$ \\
\hline NPK 12:120:36 & 19 & $3 \mathrm{~kg}$ & $2.28 \times 2$ & 4.56 \\
$\mathrm{Ca}(\mathrm{NO} 3)$ & 8 & $3 \mathrm{~kg} \mathrm{x} \mathrm{2}$ & $1.92 \times 2$ & 3.84 \\
$\mathrm{MgSo} 4$ & 11 & $1.5 \mathrm{~kg} \mathrm{x} \mathrm{2}$ & $1.32 \times 2$ & 2.64 \\
Iron Chilate & 5 & $100 \mathrm{gx} \mathrm{2}$ & $0.5 \times 2$ & 1.00 \\
Nitric acid & $44 / 20$ liter & 2 liters & 4.4 & 4.4 \\
Total & & & & 16.4 \\
\hline
\end{tabular}

Hint: each treatments prepared same amount of fertilizers used

- Cost of labor for culture practice $=2$ rials per labor $/$ day $(3$ months $/$ season $)=360$

- Cost of Seeds (1000 seeds) $=50$ O.R/season

- Cost of chemicals: 100 O.R

Power consumption for each temperature per season:

Summer Season (June-August) second year 2017/2018

\begin{tabular}{lccccc}
\hline Treatments & At planting time & End of season & Consumption kw/season & Price per $/ \mathrm{kw}$ O.R & Total price O.R \\
\hline $\mathrm{T} 1\left(22^{\circ} \mathrm{C}\right)$ & 00884 & 01654 & 1059 & 0.01 & 10.6 \\
$\mathrm{~T} 2\left(25^{\circ} \mathrm{C}\right)$ & 00696 & 01943 & 958 & 0.01 & 9.6 \\
$\mathrm{~T} 3\left(28^{\circ} \mathrm{C}\right)$ & 00217 & 00798 & 581 & 0.01 & 5.8 \\
\hline
\end{tabular}

Fall Season (Sept-Nov) second year 2017/2018

\begin{tabular}{lccccc}
\hline Treatments & At planting time & End of season & Consumption kw/season & Price per $/$ kw O.R & Total price O.R \\
\hline $\mathrm{T} 1\left(22^{\circ} \mathrm{C}\right)$ & 01988 & 02598 & 610 & 0.01 & 6.1 \\
$\mathrm{~T} 2\left(25^{\circ} \mathrm{C}\right)$ & 01703 & 02258 & 555 & 0.01 & 5.6 \\
$\mathrm{~T} 3\left(28^{\circ} \mathrm{C}\right)$ & 00823 & 01005 & 182 & 0.01 & 1.8 \\
\hline
\end{tabular}

Spring Season (Feb-May) second year 2017/2018

\begin{tabular}{lccccc}
\hline Treatments & At planting time & End of season & Consumption kw/season & Price per/kw O.R & Total price O.R \\
\hline $\mathrm{T} 1\left(22^{\circ} \mathrm{C}\right)$ & 02598 & 003476 & 878 & 0.01 & 8.8 \\
$\mathrm{~T} 2\left(25^{\circ} \mathrm{C}\right)$ & 02258 & 002776 & 518 & 0.01 & 5.2 \\
$\mathrm{~T} 3\left(28^{\circ} \mathrm{C}\right)$ & 01005 & 01249 & 244 & 0.01 & 2.44 \\
\hline
\end{tabular}

Production of cucumber and price/season for second year 2017/2018

\begin{tabular}{|c|c|c|c|c|c|c|c|c|c|}
\hline \multirow[t]{2}{*}{ RZTs } & \multicolumn{3}{|c|}{ June-August } & \multicolumn{3}{|c|}{ September-November } & \multicolumn{3}{|c|}{ February-May } \\
\hline & $\begin{array}{r}\text { Yield } \\
\mathrm{kg} / \mathrm{gh}\end{array}$ & $\begin{array}{c}\text { Price } \\
\text { O.R } / \mathrm{kg}\end{array}$ & $\begin{array}{c}\text { Total } \\
\text { income O.R }\end{array}$ & Yield kg/gh & $\begin{array}{c}\text { Price } \\
\text { O.R / } / \mathrm{kg}\end{array}$ & $\begin{array}{c}\text { Total } \\
\text { income O.R }\end{array}$ & Yield kg/gh & $\begin{array}{c}\text { Price } \\
\text { O.R / kg }\end{array}$ & $\begin{array}{c}\text { Total } \\
\text { income O.R }\end{array}$ \\
\hline $\mathrm{T} 1\left(22^{\circ} \mathrm{C}\right)$ & 6100 & 0.4 & 2440 & 8500 & 0.2 & 1700 & 8500 & 0.2 & 1700 \\
\hline $\mathrm{T} 2\left(25^{\circ} \mathrm{C}\right)$ & 6000 & 0.4 & 2400 & 8700 & 0.2 & 1740 & 7600 & 0.2 & 1520 \\
\hline $\mathrm{T} 3\left(28^{\circ} \mathrm{C}\right)$ & 3800 & 0.4 & 1520 & 7000 & 0.2 & 1400 & 7100 & 0.2 & 1420 \\
\hline $\mathrm{T} 4\left(33^{\circ} \mathrm{C}\right)$ & 3500 & 0.4 & 1400 & 6800 & 0.2 & 1360 & 6500 & 0.2 & 1300 \\
\hline
\end{tabular}

\section{Copyrights}

Copyright for this article is retained by the author(s), with first publication rights granted to the journal.

This is an open-access article distributed under the terms and conditions of the Creative Commons Attribution license (http://creativecommons.org/licenses/by/3.0/). 